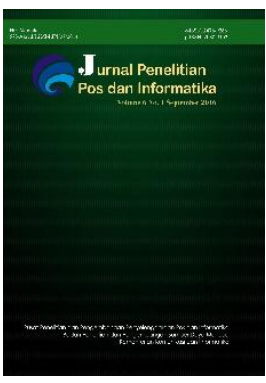

JPPI Vol 8 No 2 (2018) 123 - 140

Jurnal Penelitian Pos dan Informatika

771/AU1/P2MI-LIPI/08/2017

$32 a / E / K P T / 2017$

e-ISSN: 2476-9266

p-ISSN: 2088-9402

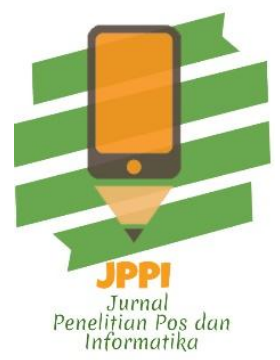

DOI:10.17933/jppi.2018.080203

\title{
EVALUASI TATA KELOLA TEKNOLOGI INFORMASI E-KTP MENGGUNAKAN FRAMEWORK COBIT (STUDI KASUS : DINAS KEPENDUDUKAN DAN CATATAN SIPIL KABUPATEN BOGOR)
}

\section{EVALUATION OF THE INFORMATION TECHNOLOGY GOVERNANCE E-KTP USING FRAMEWORK COBIT (CASE STUDY : THE DISTRICT POPULATION AND CIVILIAN BOGOR REGENCY)}

\author{
Dwi Tjahyo Kurniawan ${ }^{1}$, Yani Nurhadryani ${ }^{2}$, dan Wisnu Ananta Kusuma ${ }^{3}$ \\ Mahasiswa magister ilmu komputer, Departemen Ilmu Komputer, Sekolah Pascasarjana IPB \\ ${ }^{2}$ Software Engineering and Information Sciences, Departemen Ilmu Komputer IPB \\ Jl. Meranti Wing 20 Level 5. Kampus IPB Darmaga \\ Jl. Ciledug Raya, Petukangan Utara, Jakarta Selatan, DKI Jakarta, Indonesia $12260^{12}$
}

Email:wawankurnia77@gmail.com ${ }^{l}$

Naskah diterima: 15 Desember 2017 ; Direvisi : 28 Juli 2018 ; Disetujui : 27 November 2018

\begin{abstract}
Abstrak
Dinas Kependudukan dan Catatan Sipil Kabupaten Bogor (Disdukcapil) bertugas menjalankan sistem kependudukan elektronik kartu identitas (e-KTP). Metodologi yang digunakan berdasarkan kerangka kerjaControl Objectives for Information and related Technology (COBIT)4.1. COBITmerupakan framework yang menjembatani kesenjangan antara risiko dan masalah bisnis dengan teknis sehingga sistem informasi teknologi e-KTP berjalan sangat. Hasil analisis yang dilakukan di Dinas Kependudukan dan Catatan Sipil Kabupaten Bogor (Disdukcapil) menghasilkan nilai 2,48 yang berarti pada tingkat 2 (dapat diulang). Dinas Kependudukan dan Catatan Sipil Kabupaten Bogor telah memiliki pola untuk mengelola proses terkait berdasarkan keberhasilan pengalaman yang berulang yang pernah dilakukan sebelumnya tetapi pola yang dilakukan belum berstandar. Hasil tersebut menjadi dasar penentuan analisis gap serta rekomendasi yang diperlukan berdasarkan standar COBIT untuk Disdukcapil.
\end{abstract}

Kata kunci: COBIT, e-KTP, Teknologi Informasi.

\section{Abstract}

The District Population and Civilian Bogor Regency receive a task to run the electronic population system identity card (e-KTP). The methodology that is used based on the COBIT framework 4.1. COBIT is a framework that comprehensive as the standardization that bridge the gap between the risk and business problems with technical information technology system until the reign of the card e-KTP running very good and sustainable. The results of the analysis performed in the District Population and Civilian Bogor Regency (Disdukcapil) produce 2,48 values which means on the level 2 (can be repeated). The problems faced is the management does not understand the importance of risk management is not well managed and human resources remain less evenly. The dependence of equipment and training to the central government is very high. Produce technology control become weak. The material found compared with the ideal condition that has created Cobit in each of their levels, in order to know the appropriate recommendation to apply at Disdukcapil.

Key Words: COBIT, e-KTP, Information Technology. 


\section{PENDAHULUAN}

Kabupaten Bogor merupakan salah satu kota di propinsi Jawa Barat yang giat mengembangkan konsep e-government.Menurut Nurhadryani tahun 2009, e-government adalah pemanfaatan informasi, komunikasi, dan teknologi oleh pemerintah yang terkonsentrasi dalam pelayanan publik (Nurhadryani, 2009).Salah satu wujud pelayanan publik adalah pelayanan Kartu Tanda Penduduk Elektronik(eKTP).Pelayanan e-KTP tertuang dalam Undang Nomor 25 Tahun 2009 tentang pelayanan publik(Undang-Undang Nomor 25, 2009).

Pelayanan e-KTP kepada masyarakat, dibutuhkan sistem AdministrasiKependudukan. Sistem AdministrasiKependudukan yang saat ini berjalan di setiap daerah terbentuk sesuai amanat Undang-Undang No. 23 tahun 2006 tentang Administrasi Kependudukan. Administrasi Kependudukan berfungsi sebagai bentuk tata tertib Administrasi Negara bidang kependudukan, selain itu sebagai syarat administrasi pelayanan umum (Undang-Undang Nomor 23, 2006).

Sebagai perwujudan dari Peraturan Daerah Kabupaten Bogor No. 9 Tahun 2009, maka dibentuklah Dinas Kependudukan dan Catatan Sipil Kabupaten Bogor (Disdukcapil) yang bertanggungjawab dalam pelayanan e-KTP di wilayah Kabupaten Bogor. Selama menjalankan pelayanan e-KTP, ditemukan beberapa hambatan antara lain alat rekam yang rusak, jaringan dan server lokal yang mati, penunggalan data pada server pusat yang membutuhkan waktu 9 jam. Blangko e-KTP kosong, sedangkan permintaan blangko berdasarkan penduduk yang sudah melakukan perekaman sangat banyak. Sebagai pengganti blangko e-KTPyang kosong diterbitkan Surat Keterangan (Suket), namun dalam beberapa kasus ditemukan penolakan pada beberapa instansi pemerintahan. Permasalahan umum juga dihadapi pada daerah lain, antara lain di kota Padang dari target 26.000 wajib KTP, baru selesai 7401 kartu. Hal ini terkendala pada komunikasi, kurangnya sumber daya, pertentangan pihak lain (Putera, R. E., \& Valentina, T. R, 2011). Di daerah Sanga-Sanga Kabupaten Kutai juga dijumpai permasalahan yang sama seringnya pemadaman listrik sehingga menghambat proses pelayanan e-KTP (Rivai, A, 2017).

Permasalahan yang terjadi adalah penerapan teknologi informasi saat ini kurang selaras dengan tujuan pembentukan Disdukcapil Kabupaten Bogor. Penerapan teknologi informasi harus direncanakan dan ditata kelola dengan baik untuk mendapatkan hasil yang maksimal. Tata kelola TI memudahkan organisasi dalam melakukan monitoring dan evaluasi terhadap penerapan teknologi informasi.

Analisis tata kelola teknologi informasi sistem e-KTP pada penelitian ini menggunakan COBIT (Control Objectives for Information and related Technology). COBIT memberikan arahan yang jelas dalam menciptakan teknologi informasi sesuai kebutuhan organisasi dengan memperhatikan lingkungan baik dari dalam maupun dari luar.

Menurut Tanuwijaya dan Sarno pada tahun 2010 bahwa COBIT mendukung tata kelola TI dengan menyediakan kerangka kerja untuk mengatur keselarasan TI dengan bisnis. Selain itu, kerangka kerja juga memastikan bahwa TI memungkinkan bisnis, memaksimalkan 
keuntungan, resiko TI dikelola secara tepat, dan sumber daya TI digunakan secara bertanggung jawab(Tanuwijaya, H., \& Sarno, R, 2010).

Tujuan penelitian yang ingin dicapai adalah merancang tata kelola pemanfaatan Database e-KTP sebagai teknologi informasi pada proses pengelolaan strategis e-KTP pada Disdukcapil Kabupaten Bogor berdasarkan framework COBIT. Serta memberi masukan untuk pelayanan yang terpusat di Kabupaten diarahkan di Kecamatan.

\section{METODE PENELITIAN}

\section{Identifikasi Masalah}

Mengidentifikasi masalah melalui suatu survey dan pengisian kuisoner terhadap staf organisasi Disdukcapil Kabupaten Bogor serta analisa umum tentang permasalahan e-KTP secara umum di daerah lain. Permasalahan yang ditemukan kemudian kemudian dirumuskan dan dilakukan identifikasi terhadap bagian organisasi yang terkait langsung dalam proses e-KTP. Peran dan tanggung jawab organisasi tersebut didasarkan kepada RACI (Responsible, Accountable, Consulted and/or Informed) sesuai ketentuan pada COBIT 4.1 (ITGI, I, ISACA, 2007).

Setelah melakukan pengamatan menyeluruh dan menghasilkan Tingkat Kedewasaan, maka dihasilkan rekomendasi, kesimpulan dan saran. Hal ini yang akan menjadi acuan untuk melakukan perbaikan serta peninglkatan Tingkat Kedewasaan Tata Kelola IT.

\section{Pemetaan Domain COBIT}

Melakukan wawancara lebih mendalam dengan beberapa staf, antara lain: Kepala Bidang Pelayanan Pendaftaran Penduduk, Kepala Seksi Identitas Penduduk, Kepala Seksi Pindah Datang Dan Pendataan Penduduk, Kepala Bidang Pengelolaan Informasi Administrasi Penduduk, Kepala Seksi Sistem Informasi Administrasi Penduduk, Dan Kepala Seksi Pengolahan Dan Penyajian Data Kependudukan. Staf ini terlibat langsung dalam proses pelayanan e-KTP, sehingga bisa mendapatkan pengelompokan permasalahan yang terkait e-KTP dengan domain-domain dalam COBIT 4.1 dan proses didalamnya.

\section{Analisa Kondisi terkini}

Melakukan penilaian terhadap kondisi Tata Kelola IT menggunakan model Tingkat Kedewasaan berdasarkan COBIT 4.1. Sehingga bisa terlihat bagian organisasi yang harus mendapat perhatian dalam Tata Kelola IT.

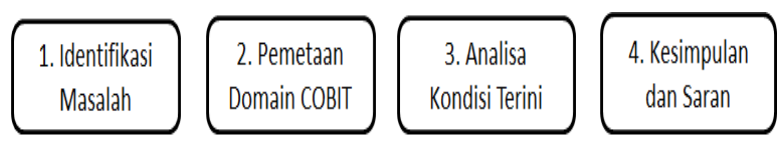

Gambar 1. Alur Penelitian 


\section{Kartu Tanda Penduduk Elektronik(e-KTP)}

E-KTP merupakan KTP yang dirancang secara elektronik dengan spesifikasi dan bentuk tertentu dan bersifat komputerisasi. E-KTP memiliki sistem basis data yang terintegrasi dengan sistem kependudukan nasional dan telah menerapkan sistem satu Nomor Induk Kependudukan (NIK)

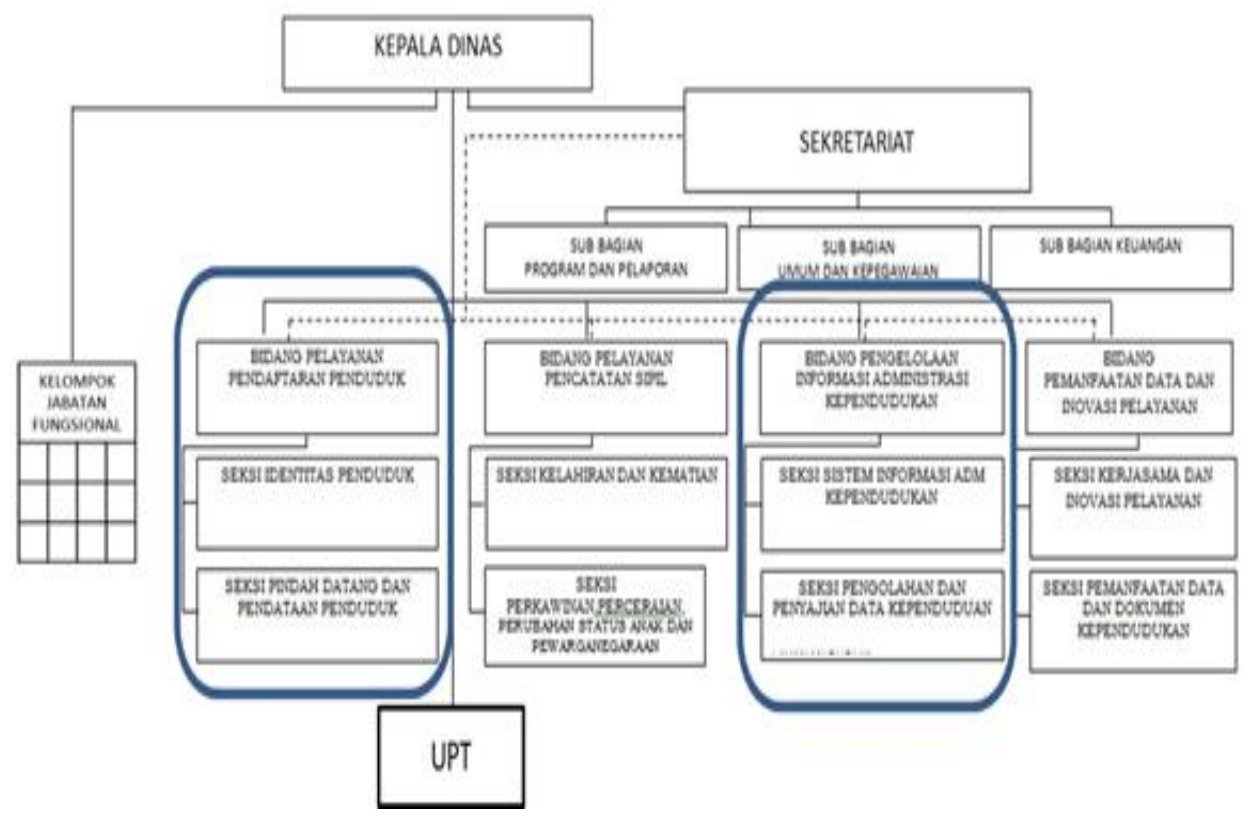

Gambar 2.Oeganisasi Disdukcapil Kabupaten Bogor Sumber : Rencana Strategis Disdukcapi

dan berlaku seumur hidup (Perpres No.26, 2009), (Undang Undang No.24, 2013). E-KTP menggunakan teknologi biometrik guna mengidentifikasi ketunggalan setiap orang Menurut Dani, Trimada-(2000), sidik jari adalah suatu hal yang unik yang di berikan oleh Tuhan untuk setiap manusia (Dani, Trimada, 2000). Sehingga salah satu komponen biometrik adalah sidik jari.E-KTP Juga harus bisa dibaca oleh Card Reader yang sudah dimiliki oleh lembaga pemerintah, swasta dan perbankan, serta agar tidak dipalsukan (Surat Edaran Mendagri nomor 471.13/1826/SJ, 2013).

\section{Organisasi Disdukcapil Kabupaten Bogor}

Organisasi Disdukcapil Kabupaten Bogor dibentuk sesuai Peraturan Daerah Kabupaten Bogor No. 9 Tahun 2009. Pembentukan organisasi ini mempunyai struktur, tugas pokok dan fungsi (Tupoksi) sesuai penjabaran pada Rencana Strategis (Rencana Strategis Dinas Kependudukan dan Catatan Sipil Kabupaten Bogor, 2003). Tupoksi organisasi harus menunjang kegiatan bisnis organisasi secara efektif dan efisien dalam pelayanan e-KTP. Kita bila lihat struktur organisasi tersebut pada gambar 2. 
Control Objectives for Information and related

Technology (COBIT) 4.1

COBIT 4.1 disusun oleh Information System Audit and Control Association (ISACA) dan merupakan model tata kelola TI yang terdiri dari kumpulan proses yang sudah diimplementasikan di semua level organisasi untuk memperbaiki tata kelola TI. COBIT mempunyai kerangka kerja bersifat spesifik yang terdiri dari beberapa domain, antara lain Plan and Organise (PO), Acquire and Implement (AI),

Deliver and Support (DS), Monitor and Evaluate (ME)(ITGI, I, Excerpt,2007).Hubungan antara proses dan sumber daya bisa dilihat pada gambar 3.

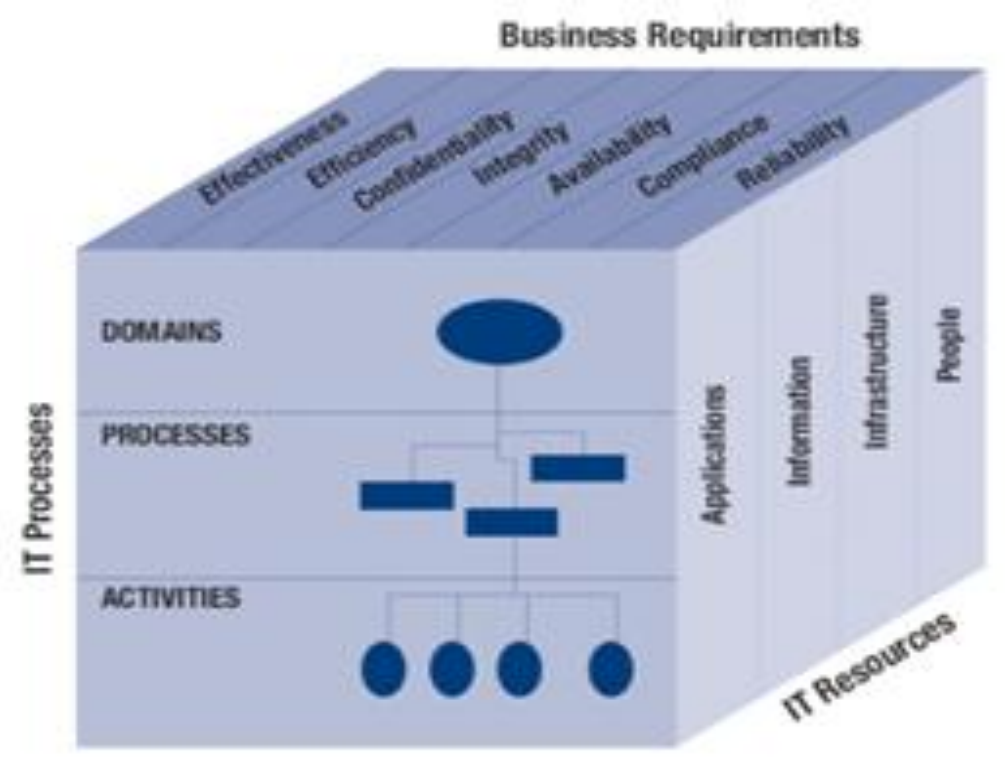

Gambar 3. Komponen COBIT

Sumber : COBIT 4.1 Excerpt Executive Summary Framework, 2007

\section{Acquire and Implement (AI)}

\section{Plan and Organize (PO)}

Membahas topik seperti strategi untuk kontribusi TI terhadap organisasi, memastikan bahwa tujuan bisnis terpenuhi. Kegiatan ini perlu direncanakan, dikomunikasikan dan dikelola, dan organisasi dan infrastruktur teknologi yang tepat harus ada dalam organisasi(ITGI, I, Excerpt, 2007).
Membahas realisasi strategi TI. Solusi telah diidentifikasi, dikembangkan atau diakuisisi, dan diterapkan. Solusi perlu diintegrasikan dalam proses bisnis. Juga termasuk dalam domain ini adalah manajemen perubahan dan pemeliharaan sistem, untuk memastikan bahwa siklus hidup dilanjutkan untuk sistem ini(ITGI, I, Excerpt,2007). 


\section{Deliver and Support (DS)}

Dalam domain ini, pengiriman aktual layanan yang dibutuhkan terjadi, mulai operasi hingga keamanan, dan termasuk pelatihan. Kegiatan ini mendukung proses yang menjadi kehidupan utama-darah organisasi. Domain ini mencakup pemrosesan data aktual oleh sistem aplikasi, yang sering diklasifikasikan dalam kontrol aplikasi (ITGI, I, Excerpt,2007).

\section{Monitoring and Evaluation (ME)}

Domain ini menangani penilaian reguler semua proses TI - semua yang sebelumnya diidentifikasi. Ini membahas seberapa baik organisasi memenuhi tujuannya melalui penggunaan sumber daya dan proses TI. Oleh karena itu, membahas pengawasan manajemen terhadap proses pengendalian organisasi dan jaminan independen yang diberikan oleh audit internal dan eksternal (ITGI, I, Excerpt,2007).

\section{Tujuan Bisnis dan Tujuan Teknologi}

COBIT mempunyai beberapa perspektif pemetaan Tujuan Bisnis, antara lain: Perspektif Keuangan, Perspektif Pelanggan, Perspektif Internal, dan Perspektif Pembelajaran. COBIT juga mempunyai pemetaan tujuan bisnis dan tujuan TI dengan metrik dan kedewasaan model untuk mengukur kinerja. COBIT terdapat 17 tujuan bisnis yang mempunyai Aktivitas TI. COBIT juga mendefinisikan tujuan TI dan mengklasifikasikannya menjadi 28 sasaran TI. Model membagi kembali TI menjadi 34 proses sesuai 4 domain (AI, PO, DS, ME) (ITGI, I, ISACA, 2007).

Tujuan bisnis yang terkait dalam penelitian ini adalah Peningkatan transparansi dan tata kelola perusahaan dan Peningkatan dan pengelolaan produktivitas operasional dan staf. Hal ini sesuai dengan misi kelima Rencana Strategis Disdukcapil tahun 2013-2018, yaitu Meningkatkan kinerja penyelenggaraan pemerintahan dan kerjasama antar daerah dalam kerangka tatakelola pemerintahan yang baik (Rencana Strategis Dinas Kependudukan dan Catatan Sipil Kabupaten Bogor, 2003)..

Demikian pula Tujuan Teknologi Informasi terkait dengan penelitian ini, antara lain : Respon terhadap kebutuhan tata kelola yang sesuai dengan arahan direksi, Perolehan dan pemeliharaan sistem aplikasi yang standar dan terintegrasi, Perolehan dan pemeliharaan infrastruktur teknologi informasi yang strandar dan terintegrasi, Jaminan akan konsistensi terhadap integrasi aplikasi ke dalam proses bisnis, Jaminan akan penggunaan dan kinerja dari aplikasi serta solusi teknologi yang sesuai, dan Penentuan kejelasan mengenai resiko dari dampak bisnis terhadap sasaran dan sumber daya teknologi informasi (ITGI, I, ISACA, 2007).

\section{Tingkat Kematangasn}

Tingkat kematangan merupakan proses untuk menentukan tingkat keselarasan biasanya dilakukan oleh auditor dengan menentukan skor melalui penilaian subjektif. ItuTerdapat nilai Tingkat kematangan menunjukkan seberapa besar kontribusi tujuan TI untuk penyelarasan terhadap bisnisatau tujuan organisasi(ITGI, I, ISACA, 2007).Pemetaan status kematangan proses teknologi informasi:

- Skala 0 (Tidak Ada); Organisasi tidak mengetahui sama sekali proses teknologi informasi. 
- Skala 1(Inisialisasi); pada level ini, organisasi pada umumnya tidak menyediakan lingkungan yang stabil untuk mengembangkan suatu produk baru.

- Skala 2(Dapat diulang); pada level ini, kebijakan untuk mengatur pengembangan suatu proyek dan prosedur dalam mengimplementasikan kebijakan tersebut ditetapkan.

- Skala 3(Ditetapkan); pada level ini, proses standar dalam pengembangan suatu produk baru didokumentasikan, proses ini didasari pada proses pengembangan produk yang telah diintegrasikan.

- Skala 4(Diatur); Pada level ini, organisasi membuat suatu matrik untuk suatu produk, proses dan pengukuran hasil.

- Skala 5(Dioptimalisasi); Pada level ini, seluruh organisasi difokuskan pada proses peningkatan secara terus-menerus.

Tabel 1. Maturity Index

\begin{tabular}{ll}
\hline Maturity Index & Maturity Level \\
\hline $0,00-0,50$ & 0-Tidak Ada \\
$0,51-1,50$ & 1-Inisialisasi \\
$1,51-2,50$ & 2-Dapat diulang \\
$2,51-3,50$ & 3-Ditetapkan \\
$3,51-4,50$ & 4-Diatur \\
$4,51-5,00$ & 5- \\
& Dioptimalisasi \\
\hline
\end{tabular}

Rincian skala kematangan terdapat dalam Tabel 1 berdasarkan COBIT 4.1 IT Governance, 2007 (ITGI, I, ISACA, 2007).: Tingkat yang tepat ditentukan berdasarkan Kerangka kerja COBIT yang memberikan kapabilitas pengelompokan perusahaan dalam mengelola TI proses dari nol (Tidak Ada) sampai lima level (Dioptimalisasi) (Sukarsa, I. M., Dita, M. Y. P., \& Purnawan, I. K. A, 2012).

\section{Penelitian terkait}

Penelitian yang dilakukan pada universitas XYZ oleh saudara Aulia dan Sri melibatkan komponen COBIT 4.1 antara lain: AI1 (solusi otomasi), AI2 (perawatan perangkat lunak), AI3 (pengoperasian aplikasi) dan AI6 (pengelolaan perubahan) untuk menghasilkan sistem tata kelola akademik. Hasil dari penelitian tersebut telah dibuat sistem tata kelola akademik dan telah dilakukan pengujian dengan tolak ukur tiga komponen COBIT serta dinyatakan bahwa tata kelola siap digunakan (Aulia, N., \& Handayaningsih, S, 2013).

Penelitian yang dilakukan di Badan Pemeriksa Keuangan menghasilkan DS3 (Manage Performance and Capacity) dan DS4 (Ensure Continuous Service) saat ini berada pada tingkat kedewasaan 2 (Repeatable but Intuitive) yang sangat bergantung pada kemampuan perseorangan, sehingga tingkat resiko tinggi untuk terjadi kesalahan. Terdapat beberapa item yang perlu diperhatikan Goal Setting dan Measurement pada proses DS4 pada level 1(Adhoc) (Purnomo, L. H. D., \& Tjahyanto, A, 2015).

Penilain tingkat kedewasaan Teknologi Informasi juga pernah dilakukan oleh Hartanto dan Tjahyanto pada tahun 2009. Aktivitas memastikan keamanan sistem (DS5) dengan atribut AC, PSP, SE, RA dan GSM menghasilkan nilai cukup baik terdapat pada level 2 (Dapat Diulang) dan aktivitas mengelola data (DS11) dengan atribut atribut AC, PSP, RA dan GSM level 3 (Proses Terdefinisi). Ekspektasi yang diharapkan pada level 5 (Dioptimalkan) (Hartanto, I. D., \& Tjahyanto, A, 2009).

Ketiga penelitian yang dilakukan sebelumnya 
menggunakan COBIT 4.1, terkait dengan penelitan yang dilakukan saat ini adalah melakukan pengembangan per item domain yang digunakan dalam penelitian. Serta pembuatan lembar kerja pada domain tertentu untuk mendukung rekomendasi yang diberikan.

\section{HASIL DAN PEMBAHASAN}

Pemetaan Permasalahan e-KTP dan tingkat kedewasaan berdasarkan Tujuan Bisnis Peningkatan Transparansi dan Tata Kelola Organisasi.

Tingkat kedewasaan pada level 3 (Ditetapkan), bisa dilihat pada tabel 2. Hal ini menunjukkan bahwa organisasi Disdukcapil sudah memahami proses e-KTP dengan detail dan melakukan perencaan dengan matang sesuai ketentuan dari Adminduk. Namun ada beberapa kendala dalam mengatasi dampak dan resiko dari permasalahan yang terjadi di level pusat. Serta perlunya penerapan dan pengawasan lebih mendalam untuk ketepatan waktu dalam mengatasi masalah dalam layanan e-KTP.

\section{PO1 (Menetapkan Rencana Strategis TI)}

Disdukcapil Kabupaten Bogor telah menyelarankan IT dengan tujuan strategi organisasi. Semua aturan dalam penerapan IT terkait e-KTP telah distandarisasi dan didokumentasikan serta disosialisasi dengan pelatihan. Tingkat keberhasilan implementasi tergantung dari tiap individu. Sudah ada perencanaan strategis yang matang tetapi belum detail seperti pengelolaan portofolio TI yang dituangkan pada rencana strategis tahun berjalan.

Perbaikan yang harus dilakukan adalah menjalankan hasil analisaStrength Weakness Opportunity Threat (SWOT) yang menghasilkan strategi Strength Opportunity (SO) adalah meningkatkan pelayanan supaya memberikan kepuasan kepada masyarakat. Strategi StrengthThreat (ST) adalah melakukan sosialisasi kepada masyarakat, dan pihak lain bahwa proses e-KTP itu memerlukan prosedur dan waktu. Strategi Weakness Opportunity (WO) adalah meningkatkan secara intensif dan maksimal koordinasi dengan lintas SKPD, lembaga Perguruan Tinggi. Strategi Weakness Threat (WT) adalah melakukan pembagian tugas yang proporsional kepada seluruh pegawai sesuai pendidikan dan keahliannya (Rencana Strategis Dinas Kependudukan dan Catatan Sipil Kabupaten Bogor, 2013). 


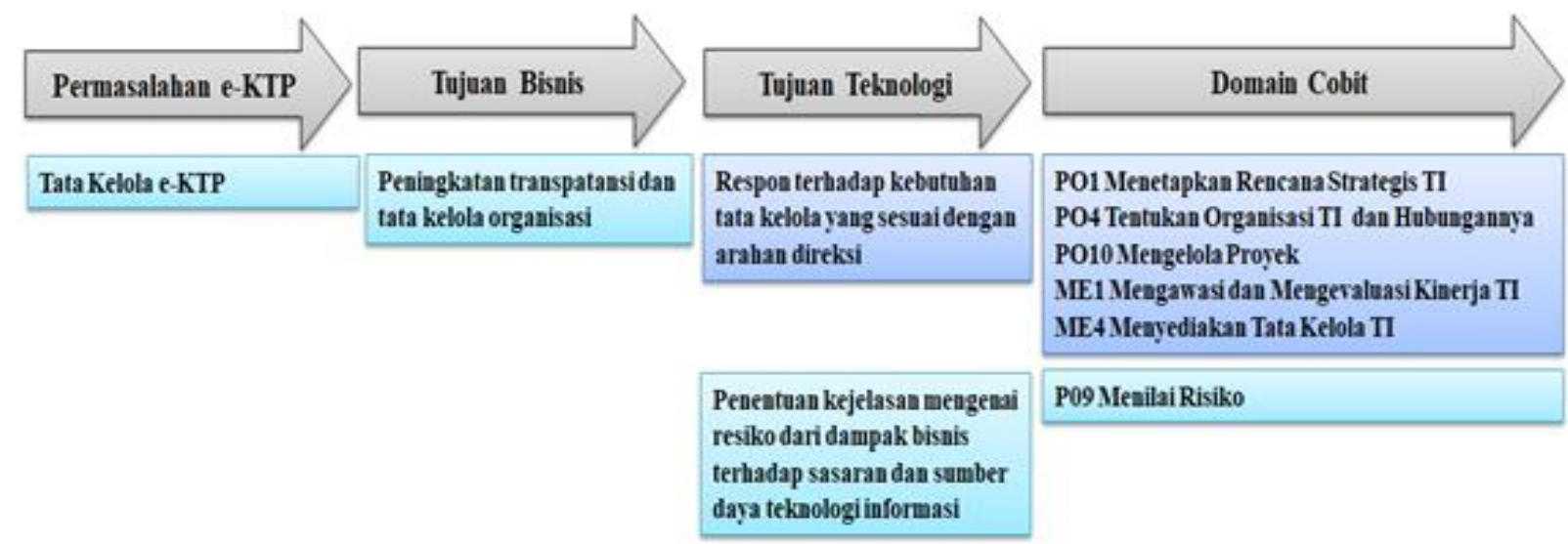

Gambar 4. Pemetaan permasalahan e-KTP berdasar Peningkatan Transparansi dan Tata Kelola Organisasi

Tabel 2. Peningkatan transparansi dan tata kelola organisasi.

\begin{tabular}{|c|c|c|c|}
\hline Domain & Keterangan & $\begin{array}{c}\text { Index } \\
\text { Maturity }\end{array}$ & $\begin{array}{l}\text { Maturity } \\
\text { Level }\end{array}$ \\
\hline $\mathrm{PO1}$ & Menetapkan Rencana Strategis TI & 2,88 & Ditetapkan \\
\hline PO4 & $\begin{array}{l}\text { Tentukan Organisasi TI dan } \\
\text { Hubungannya }\end{array}$ & 2,92 & Ditetapkan \\
\hline PO9 & Menilai Risiko & 2,17 & $\begin{array}{l}\text { Dapat } \\
\text { diulang }\end{array}$ \\
\hline PO10 & Mengelola Proyek & 3,00 & Ditetapkan \\
\hline ME1 & $\begin{array}{l}\text { Mengawasi dan Mengevaluasi } \\
\text { Kinerja TI }\end{array}$ & 2,33 & $\begin{array}{l}\text { Dapat } \\
\text { diulang }\end{array}$ \\
\hline ME4 & Menyediakan Tata Kelola TI & 2,50 & $\begin{array}{l}\text { Dapat } \\
\text { diulang }\end{array}$ \\
\hline Index & & 2,69 & Ditetapkan \\
\hline
\end{tabular}

Analisa Value Chain sesuai gambar 4 untuk memetakan kegiatan utama dan kegiatan pendukung yang tak efektif serta menganalisa TI sebagai pengganti kegiatan tersebut (Maryani, M., \& Darudiato, S, 2010). Sebagai contoh sistem pencetakan e-KTP dikakukan di kabupaten didelegasikan di Kecamatan untuk menghindari penumpukan antrian di Disdukcapil, hal ini sesuai strategi SO.

\section{PO4 (Tentukan Organisasi TI dan Hubungannya)}

Disdukcapil sudah menentukan prosesproses IT terkait e-KTP dan peran dan tanggung jawab organisasi, sehingga jelas dan tegas. Hal ini yang tertuang secara resmi dalam dokumen organsasi. Terdapat bagian khusus yang menangani kebijakan dan prosedur administrasi, sehingga peran TI dalam pengambilan keputusan menjadi semakin besar. Organisasi mempunyai kerangka proses TI, dan sudah terjabarkan sesuai tugas pokok dan fungsi tiap bagian. Kerangka proses TI sudah ditentukan oleh pihak Direktorat Admintrasi dan Kependudukan Kementerian Dalam Negeri (Adminduk).

Perbaikan yang harus dilakukan adalah pembagian tugas yang proporsional kepada seluruh pegawai sesuai pendidikan dan keahliannya TI sesuai strategi WT. Mengintegrasikan semua bagian orgaisasi dan diberi tanggungjawab yang lebih untuk terlibat dalam pengelolaan e-KTP. Mengukur tingkat efektifitas TI dan pegawai, bila Key Performace Indicator (KPI) pegawai jelek bisa dievaluasi. 
PO9 (Menilai Risiko)

Pihak Disdukcapil Kabupaten Bogor sudah mulai menyadari resiko yang timbul dan belajar dari pengalaman yang pernah terjadi. Mitigasi resiko IT belum dijabarkan secara detail dan
Perbaikan yang dilakukan adalah melakukan evaluasi secara berkala terhadap staff TI dan pembahasan berkelanjutan tentang permasalahan yang sudah terjadi. Membuat kebijakan dan standarisasi yang baku untuk
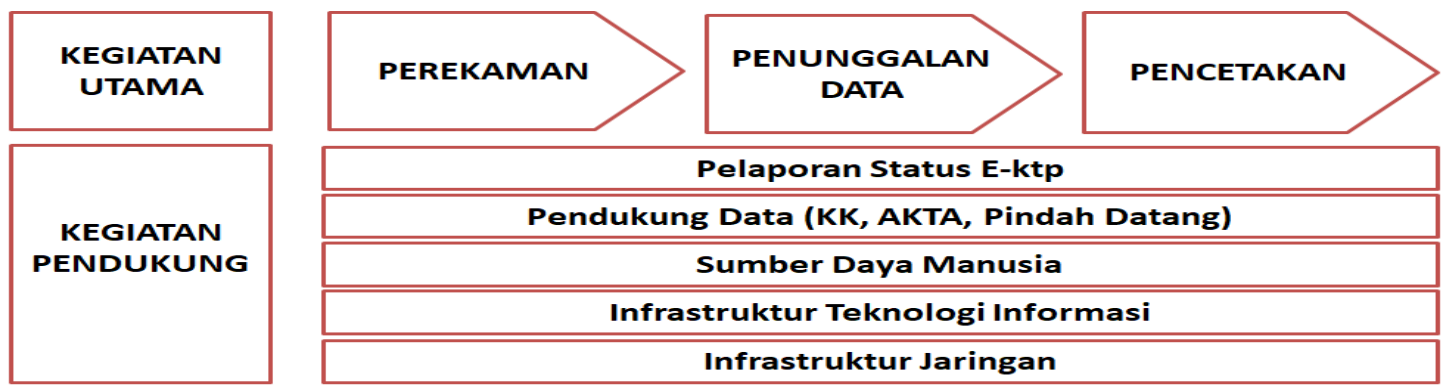

Gambar 4. Value Chain perekaman e-KTP belum didokumentasikan secara baku. Organisasi sudah memberikan tanggung jawab tentang manajemen resiko secara berjenjang kepada semua elemen organisasi dalam pelayanan eKTP.

Perbaikan adalah membuat sub organisasi yang bertugas menilai resiko TI, dimana anggotanya terdiri personel yang mewakili tugas pengolahan e-KTP. Diperlukan standarisasi mitigasi resiko TI yang diberlakukan pada tiap setiap bagian organisasi. Membuat standar pengukuran pemakaian hardware dan infrastruktur. Sehingga bisa dilakukan evaluasi secara berkala dan prediksi tingkat kerusakan alat.

\section{PO10 (Mengelola Proyek)}

Pihak Disdukcapil Kabupaten Bogor sudah menerapkan manajemen proyek untuk seluruh pekerjaan proyek IT. Keterlibatan personil IT juga terlibat dalam pengelolaan proyek. Tapi belum adanya personil yang khusus untuk menangani manajemen proyek secara utuh karena terbatasnya personil IT. perencanaan proyek dan kerjasama dengan pihak ketiga. Mementukan staf TI secara khusus untupk mendampingi setiap proyek secara penuh untuk manajemen dan pengembangan selanjutnya. Melakukan evaluasi terhadap pihak ketiga yang tidak sesuai standar kerja proyek yang telah disepakati.

\section{ME1 (Mengawasi dan Mengevaluasi Kinerja TI)}

Disdukcapil sudah menyadari perlunya pengawasan dan evaluasi kinerja TI. Tetapi pengawasan dan evaluasi kinerja TI serta mendiskusikan rencana perbaikan melalui pertemuan belum diadakan secara rutin. Pertemuan diadakan dalam kondisi tertentu bila terjadi suatu masalah krusial. Belum efektifnya sistem pengendalian dan evaluasi, baik metodologi, pelaksanaan maupun penggunaannya (encana Strategis Dinas Kependudukan dan Catatan Sipil Kabupaten Bogor, 2013).

Perbaikan yang harus dilakukan adalah melakukan audit secara berkala terhadap kinerja personel maupun efektiftas TI. Diberlakukan lembar kerja pelaporan masalah sesuai jenis dan 
prioritas penanganan, sehingga bisa diambil langkah evaluasi bila masalah tidak bisa tertangani. Serta diadakan pertemuan staf TI secara rutin untuk membahas isu dan kendala yang terjadi dan hal itu didokumetasikan untuk dikehui semua staf TI. Sebagai contoh monitoring kinerja database berfungsi melihat load database bila tinggi segera termonitoring dan dilakukan pengecekan apa ada aplikasi yang bermasalah atau media penyimpanan penuh.

\section{ME4 (Menyediakan Tata Kelola TI)}

Kerangka kerja untuk mengatur tata kelola TI saat ini sudah dilakukan mengikuti pola dari Adminduk. Hal ini disebabkan sebagian besar perangkat keras dan aplikasi didapatkan dari Adminduk dan pengembangan teknologi informasi baru dilakukan dalam jangka waktu lama dan dilakukan sesuai kebutuhan.

Perbaikan yang dilakukan membangun kerangka kerja tata kelola TI yang terintegrasi antar sub organisasi, dimana sub organisasi mempunyai tanggung jawab terhadap integritas data yang dikeluarkan. Serta menerapkan Service level Agreement (SLA) terkait kepemilikan dan pengguna proses TI dan rutin melakukan monitoring terhadap SLA. Sehingga bisa mengevaluasi tingkat ketepatan waktu dalam penyajian data dan perbaikan bila terjadi masalah proses TI.

\section{Pemetaan Permasalahan e-KTP dan Tingkat Kematangan berdasarkan Tujuan Bisnis (Peningkatan dan Pengelolaan Produktivitas Operasional dan Staf)}

Tingkat Kematanganpada level 2 (Dapat Diulang).Bisa dilihat pada tabel 3. Hal ini menunjukkan bahwa organisasi Disdukcapil untuk tujuan bisnis Peningkatan dan Pengelolaan Produktivitas Operasional dan Staf masih membebankan tanggung jawab dan prosedur kepada individu. Serta perlunya perawatan infrastruktur e-KTP secara berkala oleh pemerintah pusat selaku pembuat sistem dan pemerintah daerah sekalu kepanjangan tangan di daerah. 


\begin{tabular}{|c|c|c|c|}
\hline Permasalahan e-KTP & Tujuan Bisnis & Tujuan Teknologi & Domain Cobit \\
\hline \multirow{5}{*}{ 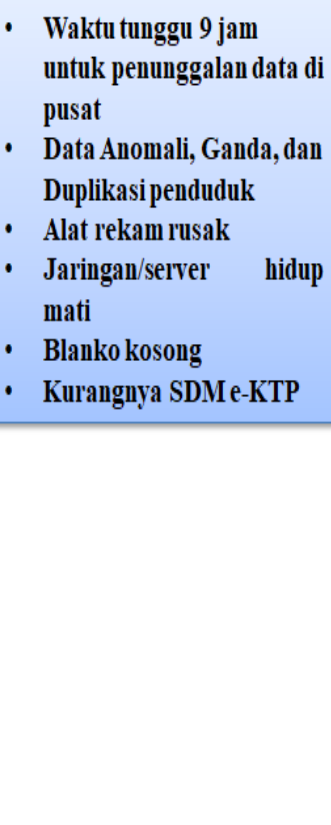 } & \multirow[t]{5}{*}{$\begin{array}{l}\text { Peningkatan dan pengelolaan } \\
\text { produktivitas operasional dan } \\
\text { staf }\end{array}$} & $\begin{array}{l}\text { Perolehan dan pemeliharaan } \\
\text { sistem aplikasiyang standar } \\
\text { dan terintegrasi }\end{array}$ & $\begin{array}{l}\text { P03 Tentukan Arah Teknologi, } \\
\text { AI1 Mengidentifikasi Solusi, } \\
\text { AI5 Sistem Install and Accredit }\end{array}$ \\
\hline & & $\begin{array}{l}\text { Perolehan dan pemeliharaan } \\
\text { infrastruktur teknologi } \\
\text { informasi yang strandar dan } \\
\text { terintegrasi. }\end{array}$ & $\begin{array}{l}\text { AI3 Memperoleh dan Memelihara Arsitektur } \\
\text { Teknologi } \\
\text { AI5 Sistem Install and Accredit }\end{array}$ \\
\hline & & $\begin{array}{l}\text { Jaminan akan konsistensi } \\
\text { terhadap integrasi aplikasi ke } \\
\text { dalam proses bisnis. }\end{array}$ & $\begin{array}{l}\text { P02 Menetapkan Arsetektur Sistem Informasi, } \\
\text { AI1 Mengidentifikasi Solusi, } \\
\text { AI7 Instalasi dan Akreditasi Solusi serta } \\
\text { Perubahan }\end{array}$ \\
\hline & & $\begin{array}{l}\text { Jaminan akan penggunaan } \\
\text { dan kinerja dari aplikasi serta } \\
\text { solusi teknologi yang sesuai. }\end{array}$ & \multirow{2}{*}{$\begin{array}{l}\text { P06 Komunikasikan Manajemen Tujuan dan } \\
\text { Arah } \\
\text { AI4 Mengembangkan dan Menjaga Prosedur TI } \\
\text { AI7 Instalasi dan Akreditasi Solusi serta } \\
\text { Perubahan } \\
\text { DS7 Mendidik dan Melatih Pengguna } \\
\text { DS8 Membantu dan Menyarankan Pelanggan IT }\end{array}$} \\
\hline & & & \\
\hline
\end{tabular}

Gambar 4. Pemetaan permasalahan e-KTP berdasar Peningkatan dan Pengelolaan Produktivitas Operasional dan Staf

Tabel 3. Peningkatan dan pengelolaan produktivitas operasional dan staf

\begin{tabular}{|c|c|c|c|}
\hline Domain & Keterangan & $\begin{array}{c}\text { Index } \\
\text { Maturity }\end{array}$ & $\begin{array}{l}\text { Maturity } \\
\text { Level }\end{array}$ \\
\hline $\mathrm{PO} 2$ & Menetapkan Arsetektur Sistem Informasi & 2,75 & Ditetapkan \\
\hline PO3 & Tentukan Arah Teknologi & 2,00 & Dapat diulang \\
\hline PO6 & Komunikasikan Manajemen Tujuan dan Arah & 2,30 & Dapat diulang \\
\hline DS7 & Mendidik dan Melatih Pengguna & 2,00 & Dapat diulang \\
\hline DS8 & Membantu dan Menyarankan Pelanggan IT & 2,80 & Ditetapkan \\
\hline Al1 & Identifikasi Solusi Terotomatisasi & 2,39 & Dapat diulang \\
\hline Al3 & $\begin{array}{l}\text { Memperoleh dan Memelihara Arsitektur } \\
\text { Teknologi }\end{array}$ & 2,72 & Ditetapkan \\
\hline Al4 & Mengembangkan dan Menjaga Prosedur TI & 1,71 & Dapat diulang \\
\hline Al7 & $\begin{array}{l}\text { Instalasi dan Akreditasi Solusi serta } \\
\text { Perubahan }\end{array}$ & 2,30 & Dapat diulang \\
\hline Index & & 2,33 & Dapat diulang \\
\hline
\end{tabular}

\section{PO2 (Menetapkan Arsitektur Informasi)}

Disdukcapil

sudah

mendefinisikanArsitektur Informasi dengan baik, dengan didukung kebutuhan akanArsitektur
Informasi sudah diterima oleh pihak internal organisasi. Rancangan Arsitektur Informasi saat ini mengacu pada Arsitektur Informasi dari Adminduk. 


\begin{tabular}{|c|c|c|c|c|c|c|}
\hline Aplikasi/Fungsi & 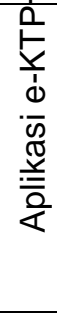 & 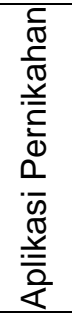 & 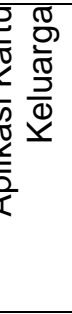 & 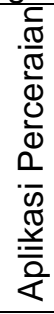 & 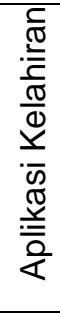 & 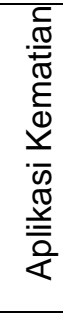 \\
\hline Rekam dan Penerbitan e-KTP & B & & & & & \\
\hline $\begin{array}{l}\text { Lapor dan Penerbitan Kartu } \\
\text { Keluarga }\end{array}$ & & $B L$ & & & & \\
\hline Lapor dan Penerbitan akta nikah & & & $\mathrm{BL}$ & & & \\
\hline Lapor dan Penerbitan akta cerai & & & & $B L$ & & \\
\hline Lapor dan Penerbitan akta lahir & & & & & $\mathrm{BL}$ & \\
\hline $\begin{array}{l}\text { Lapor dan Penerbitan akta } \\
\text { kematian }\end{array}$ & & & & & & $\mathrm{BL}$ \\
\hline
\end{tabular}

Perbaikan yang dilakukan membuat pemetaan aplikasi dan fungsi dari tingkat kabupaten sampai kelurahan. Dalam apliaksi terdapat keterangan database dan platform yang digunakan. Dalam Fungsi dijelaskan bagian yang bertanggung jawab mengeluarkan dokumen (Gustiana, I, 2016).. Hal ini mempermudah dalam pengembangan Arsitektur Informasi yang disesuaikan dengan kondisi di Disdukcapil Kabupaten Bogor. Hal ini bisa dilihat pada tabel 4.

\section{PO3 (Tentukan Arah Teknologi)}

Memiliki konsep perencanaan teknologi tapi belum diatur secara detail dalam suatudokumen dan prosedur yang baku. Perencanaan teknologi hanya bersifat jangka pendek berdasarkan kebutuhan jangka pendek.

$$
\text { Perlunya pembuatan perencanaan }
$$

teknologi yang mengikuti perkembangan jaman dan dituangkan dalam dokumentasi yang baku, seperti menghilangkan ketergantungan alat pembaca e-KTP yang diimport dari Korea dan Amerika. Badan Penerapan dan Penelitian Teknologi (BPPT) merancang alat alat pembaca e-KTP yang murah dan tepat guna (Bejo, A., Hamzah, M. F., \& Suwastono, A, 2017). Serta mudah mendapatkan alat di pasaran dan mudah dibawa kemanapun, sehingga Disdukcapil bila terjadi kerusakan alat bisa langsung melakukan pembelian alat tanpa tergantung dengan alat dari Adminduk.

\section{PO6 (Komunikasikan Tujuan dan Arah Manajemen)}

Disdukcapil sudah memiliki misi dalam Rencana Strategis yang harus dipatuhi oleh semua staf. Semua kebijakan harus dikomunikasikan kepada semua bagian organisasi. Namun belum adanya kebijakan pengelolaan resiko secara terpadu antara Adminduk dan Disdukcapil. Hasil pengamatan dilapangan ditemukan dampak dari dikeluarkannya Surat Keterangan (Suket) akibat blanko e-KTP yang kosong belum disosialisasikan kepada seluruh instansi pemerintah dan swasta. Sehingga ada beberapa instansi yang tidak menerima Suket.

Tindakan yang harus dilakukan adalah Membuat rencana pelaksanan kebijakan berupa sosialisasi, training bagi semua komponen organisasi. Menindaklanjuti Surat Edaran menteri tentang Suket dengan membuat aplkasi (Nurhadi, N, 2017). Serta membuat dokumen panduan arah dan tujuan manajeman terkait Suket untuk ditaati dan dilaksanakan semua instansi terkait. Dengan 
adanya surat edaran tesebut semua pihak dari tingkat pusat sampai daerah diharapkan bisa bersinergi dalam mengatasi masalah Suket.

\section{DS7 (Mendidik dan Melatih Pengguna)}

Training telah direncanakan dan ditetapkan sesuai dengan kebutuhan operasional. Semua fasilitas training untuk ADB ditentukan oleh Adminduk. Tetapi tidak secara rutin diadakan dan tidak semua case diangkat dalam pembahasan training tersebut. Sehingga banyak permasalahan yang belum terselesaikan atau harus menunggu tim dari pusat. Dokumentasi permasalahan dan penyelesaiannya belum baku.

Perbaikan yang harus dilakukan adalah Melakukan pengelompokan masalah pelayanan dan dilakukan standarisasi penanganannya. Intensitas training ditingkatkan untuk menambah wawasan petugas pelayanan e-KTP. Melakukan evaluasi training untuk materi dan simulasi penyelesaian masalah e-KTP.

\section{DS8 (Mengelola Bagian layanan dan insiden)}

Pihak Disdukcapil sudah membuat suatu sistem yang membantu user bila mengalami kesulitan (Helpdesk), dan sudah terintegrasi dengan helpdesk Adminduk bila ada kesulitan yang membutuhkan penanganan dari pusat. Pihak Adminduk membuat suatu forum diskusi baik dalam facebook maupun whatsapp. Anggota forum tersebut adalah ADB (Administrator Database) adanya orang yang khusus untuk menangani pelayanan data.

Perbaikan yang harus dilakukan adalah pembuatan help desk internal pada Disdukcapil yang menampung dokumentasi lengkap tentang kejadian, proritas penanganan, sistem penanganan, siapa yang bertanggung jawab. Membuat evaluasi dan laporan bulanan terhadap dokumentasi kejadian, bila menyangkut hardware atau sistem yang sering bermasalah, perlu adanya solusi permanen yaitu pengadaan ulang dan pengembangan sistem.

\section{AI1 (Mengidentifikasi solusi yang dapat diotomatisasi)}

Pendefinisian dan kebutuhan akan proses TI sudah dipahami dan dimengerti oleh Disdukcapil. Sudah ada dokumen yang mengikuti dokumen induk dari Adminduk namum penjabaran dan tanggungjawab dalam pelaksanaan sistem TI masih bersifat tergantung individu. Bisa kita lihat pada tabel 5.

Setelah dikelompokkan antara proses utama dan proses pendukung melaluai diagram value chain, kita bisa mengamati proses pendukung yang mempunyai nilai vital tinggi bila diotomasi. Kita bisa ambil contoh sistem pelaporan status e-KTP, bagian ini sangat vital untuk konsolidasi data proses utama. Serta memberi data yang akurat tentang performa pelayanan e-KTP. 
Tabel 5. Data Bagian yang Terotomatisasi

\begin{tabular}{|l|l|}
\hline \multicolumn{2}{|c|}{ Matrik Sistem Terotomatisasi } \\
\hline $\begin{array}{l}\text { Bagian yang } \\
\text { diotomasitasi }\end{array}$ & $\begin{array}{l}\text { Sistem Pelaporan Status e-KTP dan Pindah } \\
\text { Datang }\end{array}$ \\
\hline Keunggulan & $\begin{array}{l}\text { Bisa melihat status e-KTP dan jumlah } \\
\text { penduduk secara real time }\end{array}$ \\
\hline Peralatan & Server, Monitor, Keyboard, Mouse \\
\hline Jaringan & $\begin{array}{l}\text { Server terhubung dengan server e-KTP di } \\
\text { Disdukcapil }\end{array}$ \\
\hline Sisten Aliran Data & $\begin{array}{l}\text { Data penduduk yang direkam dari } \\
\text { kecamatan dan kabupaten otomatis masuk } \\
\text { server disdukcapil dan masuk dalam kolom } \\
\text { nama daerah, jumlah perekaman, jumlah } \\
\text { pencetakan. Demikian pula untuk Pindah } \\
\text { datang, data dari kelurahan bisa langsung } \\
\text { teragregasi jumlah penduduk pindah keluar } \\
\text { dan masuk. Data Pindah harus sama } \\
\text { dengan data Adminduk. }\end{array}$ \\
\hline
\end{tabular}

Kondisi saat ini adanya perbedaan data penduduk antara Adminduk dan Disdukcapil.

Hal ini terjadi karena perhitungan domisili penduduk di suatu daerah berbeda dengan data eKTP, sehingga perlu sinkronisasi data antara Adminduk dan Disdukcapil.

\section{AI3 (Memperoleh dan Memelihara Infrastruktur Teknologi)}

Pengadaan dan pemeliharaan infrastruktur TI di Disdukcapil Kabupaten Bogor sudah dijabarkan dengan jelas dalam dokumen yang baku dan sudah dimengerti oleh semua pihak terkait. Tapi pemelihaan tersebut mengikuti arahan dari Adminduk. Infrastruktur ini sangat mendukung berjalannya pelayanan e-KTP di Kabupaten Bogor. Namum ada beberapa kendala terkait putusnya jaringan dalam beberapa waktu sehingga berdampak waktu tunggu perekaman dan pengiriman data untuk penunggalan di pusat.

Perbaikan yang harus dilakukan adalah melakukan penentuan sistem pemeliharaan infrastruktur teknologi dan model bisnis dengan pihak ketiga sekalu penyedia infrastruktur. Hal ini terkait dengan budget organisasi. Adanya transfer teknologi dengan pendampingan dalam pemeliharaan infrastruktur. Diadakan audit secara berkala untuk tingkat keberhasilan penggunaan dan menentukan pengembangan infrastruktur berikutnya.

Kasus putusnya jaringan bisa diatasi dengan pembuatan backup data sementara di tingkat kecamatan dan kelurahan dan dilakukan pengiriman ulang waktu jaringan sudah normal. Serta memanggil pihak ketiga yang membangun infrastruktur tersebut untuk melakukan investigasi dan perbaikan bersama internal tim Disdukcapil.

\section{AI4 (Menjalankan operasi dan menggunakannya)}

Disdukcapil Kabupaten Bogor sudah memiliki pengaturan operasional dan solusi TI guna memenuhi kebutuhan pelayanan e-KTP. Namum belum ada dokumentasi operasional yang standar dan detail digunakan oleh organisasi. Sehingga bila terjadi masalah kurangnya staf dalam bagian tertentu bisa langsung diperbantukan dari bagian lain dan hal ini membutuhkan waktu pembelajaran lama karena tidak adanya standar manual operasional.

Perbaikan yang harus dilakukan adalah pembuatan standarisasi manual operasional 
terkait procedure kerja, membuat indikator kinerja, semua itu dimasukkan dalam sebuah ekatalog sehingga mudah dalam pencarian materi. Menentukan orang yang tepat sesuai kemampuan sesuai strategi hasil analisa SWOT (Rencana Strategis Dinas Kependudukan dan Catatan Sipil Kabupaten Bogor, 2013). Peningkatan intensitas training dan pertemuan internal untuk sharing operasional, kendala, dan penyelesaian dalam pelayanan e-KTP.

\section{AI7 (Instalasi dan Akreditasi Solusi serta Perubahan)}

Disdukcapil Kabupaten Bogor sudah mempunyai prosedure dalam melakukan perubahan baik sistem dan operasional, kondisi ini terkait perubahan peraturan pelayanan e-KTP dengan melakukan pelatihan dan perencanan implementasi berdasarkan arahan dari Adminduk. Namun pola dan uji perubahan itu tidak bisa dibakukan karena terkendala kondisi tiap daerah dan infrastruktur. Sebagai contoh Saat ini penerapan klarifikasi data anomali, ganda dan duplikat NIK bisa dilakukan di tingkat
Disdukcapil, dimana awalnya di tingkat pusat. Hal ini disebabkan klasifikasi anomali tiap daerah berbeda beda, tapi tetap menggunakan klasifikasi anomali dari pusat. Serta kemampuan tim IT Disdukcapil masih memerlukan pendampingan oleh pihak ketiga dalam pengembangan aplikasi

Perbaikan yang dilakukan adalah melakukan pengujian sistem yang dibangun sesuai matrik sistem terotomatisasi (tabel 5). Seberapa efektif dan efisien sistem yang dibangun serta kemampuan sistem untuk memenuhi ekspektasi dan kemudahan operasional bagi user. Bila sistem sudah terbangun perlu adanya sosialisasi yang intensif untuk memenuhi keinginan user. Aplikasi yang terbangun sudah terintegrasi, tidak boleh mengganggu performa aplikasi lain. Terkait kasus data ganda dan anomali dilakukan tes kemampuan software dalam menjalankan script kreteria ganda dan anomali sesuai kasus yang dikumpulkan dari semua daerah.

Perhitungan Tingkat Kedewasaan selerih domain yang terkait

Tabel 6. Tingkat Kematangan seluruh domain

\begin{tabular}{llrl}
\hline DOMAIN & \multicolumn{1}{c}{ KETERANGAN } & $\begin{array}{c}\text { MATURITY } \\
\text { INDEX }\end{array}$ & $\begin{array}{c}\text { MATURITY } \\
\text { LEVEL }\end{array}$ \\
\hline AI1 & Menetapkan Rencana Strategis TI & 2,39 & Dapat diulang \\
AI3 & Memperoleh dan Memelihara Arsitektur Teknologi & 2,72 & Ditetapkan \\
AI4 & Mengembangkan dan Menjaga Prosedur TI & 1,71 & Dapat diulang \\
AI7 & Instalasi dan Akreditasi Solusi serta Perubahan & 2,30 & Dapat diulang \\
DS7 & Mendidik dan Melatih Pengguna & 2,00 & Dapat diulang \\
DS8 & Membantu dan Menyarankan Pelanggan IT & 2,80 & Ditetapkan \\
ME1 & Mengawasi dan Mengevaluasi Kinerja TI & 2,33 & Dapat diulang \\
ME4 & Menyediakan Tata Kelola TI & 2,50 & Dapat diulang \\
PO1 & Menetapkan Rencana Strategis TI & 2,88 & Ditetapkan \\
PO2 & Menetapkan Arsetektur Sistem Informasi & 2,75 & Ditetapkan \\
PO3 & Tentukan Arah Teknologi & 2,00 & Dapat diulang \\
PO4 & Tentukan Organisasi TI dan Hubungannya & 2,92 & Ditetapkan \\
PO6 & Komunikasikan Manajemen Tujuan dan Arah & 2,30 & Dapat diulang \\
PO9 & Menilai Risiko & 2,17 & Dapat diulang \\
PO10 & Mengelola Proyek & 3,00 & Ditetapkan \\
\hline Index & & 2,48 & Dapat diulang \\
\hline
\end{tabular}


Hasil perhitungan mendapati rata-rata nilai domain tata kelola teknologi informasi pada disdukcapil Kabupaten Bogor bernilai 2,48, berarti masuk level 2 (Dapat Diulang), bisa dilihat pada tabel 6. Hal ini berarti bahwa pengelolaan TI sudah terintegrasi dengan strategi organisasi tapi masih belum merata pada bagian tertentu, mengandalkan individu dan bersifat adhoc, dimana hal ini terlihat dari belum dimilikinya Rencana Strategis TI yang dijabarkan secara detail. Kondisi ini juga terjadi karena sebagian besar pengadaan atau investasi TI dilakukan secara parsial dan tidak didukung perencanaan yang matang dan masih bergantung terhadap pemerintah pusat.

\section{DAFTAR PUSTAKA}

Bejo, A., Hamzah, M. F., \& Suwastono, A. (2017). Perancangan Smart Card Reader Menggunakan STM32F4 Discovery Kit. Jurnal Nasional Teknik Elektro dan Teknologi Informasi (JNTETI), 6(3).

Nurhadi, N. (2017). Pengaruh pelayanan dan produk jasa terhadap komitmen penerimaan nasabah pada Bank BRI tigaraksa (studi kasus pelayanan pada nasabah baru dalam kependudukan suket dari catatan sipil).Moneter-Jurnal Akuntansi dan Keuangan, 4(1), 84-90.

Rivai, A. (2017). Implementasi Pelayanan E-KTP Di Kantor Camat Sanga Sanga Kabupeten Kutai Kartanegara. Jurnal Paradigma (JP), 3(3), 291-300.

Gustiana, I. (2016). Sistem Informasi Kependudukan Dan Catatan Sipil
Menggunakan Enterprise Architecture

Planning (Studi Kasus Pemerintah

Daerah) Oleh. Jurnal Manajemen Informatika, 1(06).

Purnomo, L. H. D., \& Tjahyanto, A. (2015, July). Perancangan Model Tata Kelola Ketersediaan Layanan TI Menggunakan Framework Cobit Pada BPK-RI. In Seminar Nasional Informatika (SEMNASIF) (Vol. 1, No. 5).

Sembiring, S. W., Mudjihartono, P., \& Rahayu, S. (2015, July). Evaluasi Penerapan Teknologi Informasi di PT. Prudential Indonesia Menggunakan Model COBIT Framework 4.1. In Seminar Nasional Informatika (SEMNASIF) (Vol. 1, No. $1)$.

Aulia, N., \& Handayaningsih, S. (2013). Pembuatan Model Tata Kelola IT untuk Proses Akademik Menggunakan Cobit 4.1 (Studi Kasus: Universitas XYZ). Jurnal Sarjana Teknik Informatika, 1(1)

Renstra 2013. (2013). Rencana Strategis Dinas Kependudukan dan Catatan Sipil Kabupaten Bogor tahun 2013-2018.

Surat Edaran Mendagri nomor 471.13/1826/SJ.(2013). Hal pemanfaatan ektp dengan menggunakan card reader.

Surat Edaran Nomor 471.13/10231/Dukcapil. (2013). Tentang Format Surat Keterangan sebagai Pengganti KTP-el.

Undang Undang No.24 Tahun 2013. (2013). tentang Administrasi Kependudukan revisi UU no. 23 tahun 2006 tentang 
Administrasi Kependudukan pasal 64 tentang Penerapan KTP seumur hidup.

Sukarsa, I. M., Dita, M. Y. P., \& Purnawan, I. K. A. (2012). Assesment Of Cobit Maturity Level. International Journal of Computer Science and Information Security, 10(6), 41.

Putera, R. E., \& Valentina, T. R. (2011). Implementasi Program KTP Elektronik (e-KTP) di Daerah Percontohan.MIMBAR, Jurnal Sosial dan Pembangunan, 27(2), 193-201.

Maryani, M., \& Darudiato, S. (2010). Perancangan Rencana Strategis Sistem Informasi dan Teknologi Informasi (SI/TI): Studi Kasus STMIK XYZ. CommIT (Communication and Information Technology) Journal, 4(2), $77-85$

Tanuwijaya, H., \& Sarno, R. (2010). Comparation of COBIT maturity model and structural equation model for measuring the alignment between university academic regulations and information technology goals.IJCSNS, 10(6), 80 .

Hartanto, I. D., \& Tjahyanto, A. (2009). Analisa kesenjangan tata kelola teknologi informasi untuk proses pengelolaan data menggunakan cobit (studi kasus badan pemeriksa keuangan republik indonesia). Magister Manajemen Teknologi, ITS Surabaya.
Nurhadryani, Y. (2009). Memahami konsep eGovernance serta hubungannya dengan e-Government dan e-Demokrasi. In Di dalam: Seminar Nasional Informatika (Vol. 2009, pp. 111-117).

Peraturan Daerah Kabupaten Bogor No. 9 Tahun 2009.(2009). Tentang Penyelenggaraan Administrasi Kependudukan.

Perpres No.26 Tahun 2009.(2009). Tentang Penerapan KTP berbasis Nomor Induk Kependudukan Secara Nasional.

Undang-Undang Nomor 25 Tahun 2009.(2009). Tentang Pelayanan Publik.

ITGI, I. (2007). Governance Institute: CObIT 4.1 Excerpt. Executive Summary.

ITGI, I. (2007). Governance Institute: CObIT 4.1, ISACA.

UU no. 23 tahun 2006.(2006). Tentang Administrasi Kependudukan.

Dani, Trimada. (2000). Buku Petunjuk Teknis Polri di Bidang Identifikasi (Jilid 2). Jakarta: Departemen Pertahanan Markas Besar Kepolisian Negara Republik Indonesia. 